\author{
Alicja Kargulowa \\ ORCID 0000-0003-0581-1884
}

\title{
PROFESOR OLGA CZERNIAWSKA WSPÓŁTWÓRCZYNIĄ SIECI BADAŃ NAD PORADNICTWEM
}

\begin{abstract}
Słowa kluczowe: poradnictwo, poradoznawstwo, sieci społeczne, węzły i koncentratory.

Streszczenie: Artykuł wnosi wkład do historiografii poradoznawstwa, poddając analizie rozwój badań nad poradnictwem w latach 1979-1995. Jako narzędzie do opisu i analizy wykorzystano teorię sieci, wskazując w jaki sposób powiązania osobiste i funkcjonalne badaczy poradnictwa w podanym okresie doprowadziły do początków kształtowania się nowej nauki. Pozwoliło to jednocześnie na uwypuklenie roli, jaką w tych procesach pełniła prof. Olga Czerniawska. Wymowę tekstu wzmacniają rysunki sieci przedstawiających struktury wybranych seminariów Poradnictwo we współczesnym społeczeństwie.
\end{abstract}

Jak możemy przeczytać w książce znanego brytyjskiego historyka Nialla Fergusona sieci sa już dziś praktycznie wszędzie. [...] Niektóre sieci tacza ze soba bojowników, inne-medyków, a jeszcze inne-zautomatyzowane bankomaty. [...] Niektóre sieci-nader często definiowane sa jako ,rozlegte” - mają zasięg międzynarodowy, inne - zaledwie regionalny; niektóre sa ulotne, a inne podziemne (Ferguson, 2020, s. 32). Nie są to jedyne przykłady istniejących sieci, ani wszystkie ich cechy. Jednak już ta krótka charakterystyka wystarczy, by zwrócić uwagę, że żyjemy w „epoce sieci”. Jak pisze wspomniany autor, Parag Khanna zaproponowat nawet powolanie nowej dyscypliny naukowej - polaczeniografii (,, Connectografy”) - po to, by można byto lepiej śledzić ,ogólnoświatowa rewolucje sieciowa" (Ferguson, 2020, s. 35). Wprawdzie nauka taka nie powstała, jednakże w badaniach naukowych od 1980 roku słowo „sieć” zrobiło zawrotną karierę, a śledzenie rozwoju różnych zjawisk społecznych przyczyniło się do ujawniania ich sieciowego charakteru. Tutaj chcę także do tego nawiązać, gdy w tym, już kolejnym artykule (Kargulowa, 2015; 2018), odwołuję się do fragmentu życia naukowego prof. Olgi Czerniawskiej, który poświęciła zespołowym badaniom poradnictwa, czyli tworzeniu swoistej naukowej sieci. 
Chcę przywołać Jej udział w budowaniu sieci poradoznawczej, czyli w budowaniu sieci badań zorientowanych na tworzenie nauki o poradnictwie. Nazwa „poradoznawstwo” nie została przez Nią w pełni zaakceptowana, jednak nie tylko znaczący i wręcz pionierski Jej wkład w jej tworzenie był ważny zarówno ze względu na prowadzone badania, jak i dzięki tworzeniu sieci powiązań i byciu w nich w skali krajowej i międzynarodowej. Rozpoczęło się to opublikowaniem książki Poradnictwo jako wzmacnianie środowiska wychowawczego (1977), następnie owocowało licznymi artykułami (por. Woźnicka, 2015), a w pełni rozwinęło wówczas, gdy włączyła się w dysputy prowadzone w ramach ogólnopolskiego seminarium naukowego Poradnictwo we współczesnym społeczeństwie, organizowanego w latach 1989-1985 w Instytutach Pedagogiki i Psychologii Uniwersytetu Wrocławskiego, na którym zainicjowała ogląd poradnictwa z własnego - oryginalnego jak na owe czasy - punktu widzenia.

Mówiąc językiem teorii sieci, seminarium to było swoistym dość prężnym koncentratorem (Castells, 2008, str. 414-415), utworzonym dzięki spotkaniu się badaczy pochodzących z różnorodnych ośrodków, jak też tych refleksyjnych praktyków, którzy podejmowali trud wyjaśnienia, czym jest poradnictwo, jaka jest jego społeczna rola i znaczenie, jaka jest realna organizacja i zakładana lub osiągana efektywność. Udział w seminarium poszczególnych uczestników był nie tylko okazją do przedstawienia swoich poglądów na ten temat, ale również stwarzał możliwości skonfrontowania ich z poglądami innych, a także poszerzania sieci osobistych badaczy tego zagadnienia. O ile sama organizacja seminarium jako inicjatywa zrodzona w małej grupie wrocławskich badaczy (prof. Marian Kulczycki, dr Alicja Kargulowa, dr Marian Jędrzejczak, mgr Bogdan Sujak) dawała podstawy tworzeniu się sieci ustrukturyzowanej i systematycznej, czyli sformalizowanej, o tyle warunki, w jakich odbywały się spotkania, a przede wszystkim przerwy w obradach, wieczorne spacery, zakwaterowanie uczestników - ze względu na ówczesne możliwości - we wspólnych kilkuosobowych pokojach, sprzyjały rodzeniu się sieci spontanicznych i samoorganizujących się. Jawiły się one jako struktury zupełnie naturalne dla ludzi dysponujących określoną wiedzą, na co dzień odtwarzających i przekazujących ją w trakcie prowadzenia zajęć akademickich lub uprawiania poradniczej praktyki. W okresie, kiedy niedostępny był jeszcze telefon komórkowy i Internet, to one ułatwity nam realizację wrodzonej, pradawnej chęci do tworzenia sieci (Ferguson, 2020, s. 42), chęci, która dziś, pomimo rozwoju zwiększonej możliwości połączeń, dotkliwie została zablokowana przez rozwój pandemii.

Ponieważ sieć, tworzona przez badaczy poradnictwa w swojej pierwotnej formie jako cykliczne seminarium naukowe, została zerwana, często spotykałam się z pytaniem, dlaczego do tego doszło. Dotychczas nie umiałam znaleźć na nie pełnej odpowiedzi. Po latach w sukurs przyszły mi podpowiedzi Fergusona opisującego powstawanie, rozwój i upadek wielkich międzynarodowych sieci (Ferguson, 
2015; 2020). Wydaje mi się, że sieć badań poradnictwa podlegała działaniom podobnych sił i przechodziła podobne procesy rozwoju, jak opisane przez niego wielkie wydarzenia, mające miejsce w skali ogólnoświatowej.

\section{Konstruowanie sieci badań nad poradnictwem}

Aby odtworzyć pełną historię struktury sieci badań poradoznawczych, trzeba by nie tylko sięgnąć do materiałów z kolejnych spotkań i pokazać przynajmniej w przybliżeniu udział uczestniczących w nich poszczególnych zespołów lub pojedynczych osób, ale również przeprowadzić wywiady, by uzyskać informacje na ile branie udziału w seminarium było okazją do nawiązania nowych sieci, a na ile tylko ich odnowienia lub nawet zerwania. Zabieg taki jest niemożliwy z wielu powodów, w związku z tym w sposób skrócony i znacznie uproszczony przedstawię to zjawisko, jakim jest tworzenie się sieci badań nad poradnictwem i udziału w tym prof. Olgi Czerniawskiej, korzystając z materiałów pokonferencyjnych ${ }^{1}$ i własnych wspomnień.

Pierwsze spotkanie z Jej udziałem, inauguracyjne, zorganizowane pod rozbudowanym tytułem Rola poradnictwa $i$ doradztwa w optymalizacji rozwoju osobowości i podnoszeniu kultury pedagogicznej społeczeństwa (Wrocław, 26-28.XI.1979) zgromadziło badaczy ze stosunkowo niewielu ośrodków. Wrocław oprócz inicjatorów reprezentowali uczniowie prof. Kulczyckiego, wówczas magistrzy: Grażyna Dolińska, Alicja Kuczyńska, Hanna Makowska, Jan Pietraszko oraz doc. dr Maria Porębska i dr Barbara Szymańska; Warszawę - psychologowie z UW: prof. Antonina Gurycka i dr. Wanda Sztander; prof. Wanda Rachalska z Instytutu Kształcenia Zawodowego oraz mgr Grażyna Kik i mgr Teresa Opolska z Instytutu Badań nad Młodzieżą; Łódź - prof. Olga Czerniawska, prof. Włodzimierz Fijałkowski, dr Ewa Marynowicz-Hetka i mgr Małgorzata Rosin; Bydgoszcz - doc. dr Henryk Kaja i dr Andrzej Klimentowski; WSP w Zielonej Górze doc. dr Alojzy Matuszczyk i mgr Czesław Cetner; Poznań - prof. Stanisław

\footnotetext{
Wszystkie wymieniane tu tytuły seminariów i referatów są tytułami tekstów wydrukowanych w materiałach z poszczególnych seminariów, których notę bibliograficzną zamieszczam poniżej: Kargulowa, A., Jędrzejczak, M. (red.). (1980). Rola poradnictwa i doradztwa woptymalizowaniu rozwoju osobowości i podnoszeniu kultury pedagogicznej społeczeństwa. Acta Universitatis Wratislaviensis, 608). Wrocław: Wydaw. UWr.; Kargulowa, A., Jędrzejczak, M. (red.). (1982). Społeczne ijednostkowe znaczenie poradnictwa (=Acta Universitatis Wratislaviensis, 662). Wrocław: Wydaw. UWr.; Kargulowa, A., Jędrzejczak, M. (red.). (1985). Teoretyczne imetodologiczne problemy poradoznawstwa (=Acta Universitatis Wratislaviensis, 811). Wrocław Wydaw. UWr.; Jędrzejczak, M, Kargulowa, A. (red.). (1988). Perspektywy rozwoju teorii i praktyki poradnictwa (=Acta Universitatis Wratislaviensis, 1001). Wrocław. Wydaw. UWr.; Kargulowa, A. (red.). (1990). Poradnictwo wobec złożoności problemów człowieka i świata (=Acta Universitatis Wratislaviensis, 1249). Wrocław: Wydaw. UWr.; Kargulowa, A. (red.). (1995). Poradnictwo wokresie transformacji kulturowej (=Acta Universitatis Wratislaviensis, 1700). Wrocław: Wydaw. UWr.; Kargulowa, A. (red.). (1996). Dramaturgia poradnictwa (=Acta Universitatis Wratislaviensis, 1889). Wrocław: Wydaw. UWr.
} 
Szajek; Gdańsk - dr Szczepan Skrzypiec². Gdyby chcieć przedstawić ogólną strukturę sieci w chwili jej rodzenia się, biorąc pod uwagę miasta, z których pochodzili uczestnicy, pracownicy naukowi uczelni lub instytutów badawczych, można ująć ją następująco:

I SEMINARIUM

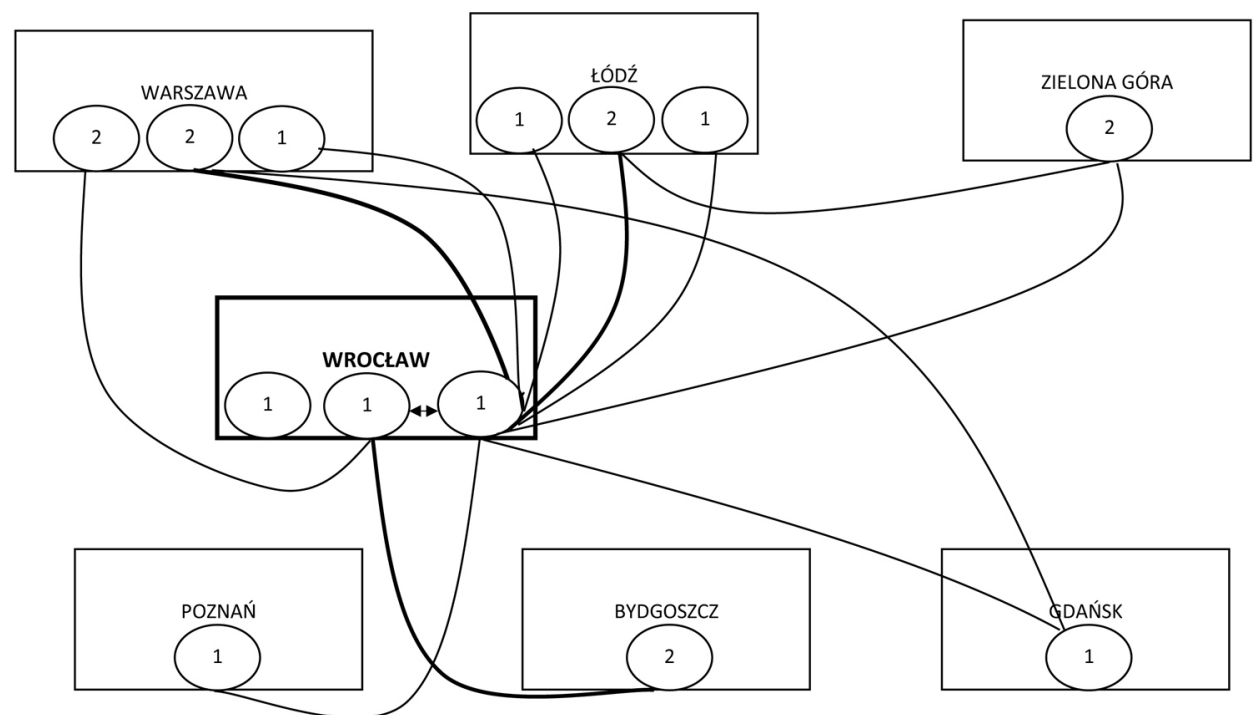

Kółka oznaczają ilość ośrodków (węzłów) w danej miejscowości, które reprezentowali referenci, i liczbę osób występujących na seminarium. Grubość linii określa wkład danego zespołu lub pojedynczej osoby w budowanie sieci badań nad poradnictwem.

\section{Rys. 1. Sieć I seminarium badań nad poradnictwem}

Dla konstruującej się merytorycznej sieci istotniejszy jednak od miejsca pracy był obszar zainteresowań badawczych uczestników. Świadczyły o tym ich dotychczas prowadzone badania i opublikowane ich wyniki. Przy bardzo ogólnym podziale podjętych w nich zagadnień można wyróżnić naukowe analizy dotyczące poradnictwa zawodowego: Warszawa, Poznań, Gdańsk; psychologicznych podstaw poradnictwa egzystencjalnego: Wrocław i Bydgoszcz; poradnictwa andragogicznego: Łódź i Zielona Góra; podstaw poradoznawstwa: Wrocław. I właśnie taki powstał podział problematyki seminarium, na czym zaważyły wiodące wówczas referaty. Były to wystąpienia dotyczące (1) poradnictwa zawodowego: prof. Rachalskiej Rola poradnictwa zawodowego w ksztaltowaniu osobowości zawodowej i prof. Szajka Rola poradnictwa i doradztwa w optymalizacji wyboru

2 W artykule podaję nazwiska i imiona oraz aktualne wówczas stopnie naukowe uczestników seminarium, aby współczesny Czytelnik mógł zorientować się, którzy z nich pozostali znanymi badaczami poradnictwa lub zrobili inną karierę naukową, a ilu rozstało się z takimi zamiarami. 
zawodu i kierunku studiów przez uczniów liceów ogólnokształcacych. Psychologiczne podstawy poradnictwa egzystencjalnego (2), które zakreślili prof. Kulczycki przedstawiając Poradnictwo życiowe i doc. dr Kaja omawiając Założenia teoretyczne poradnictwa życia. W zagadnienia poradnictwa andragogicznego (3) wprowadziła nas właśnie doc. dr Czerniawska, wygłaszając referat Poradnictwo wychowawcze dla dorostych. Wzmocnili tę problematykę dr Marynowicz-Hetka wystąpieniem Doradztwo w socjalno-wychowawczym wspomaganiu rodzin oraz doc. dr Matuszczyk Popularyzacja wiedzy o wychowaniu jako jedna z form dziatalności profilaktycznej poradni wychowawczo-zawodowej, zwracając uwagę na niektóre instytucjonalne formy tegoż poradnictwa. Ogólny zarys badań poradoznawczych (4) zapowiadał referat dr Kargulowej Metodologiczne problemy badań nad poradnictwem. Pozostałe wystąpienia niczym nie ustępując wymienionym, w różnym stopniu nawiązywały do wspomnianej problematyki, poszerzając jej obszar przez penetrację bardziej szczegółowych zagadnień. Wymienione cztery obszary-węzły utworzyły sieć tematyczną seminarium, która w trakcie jego rozwoju podlegała różnorodnym korektom, poprzez przyłączanie się do seminarium i odchodzenie zeń poszczególnych badaczy lub lokalnych zespołów.

\section{Rozwój sieci badań poradoznawczych}

W spotkaniu drugim Społeczne i jednostkowe znaczenie poradnictwa (Karpacz, 4-6. V. 1981) wzięła udział znacznie większa liczba osób i znacznie rozszerzył się zakres poruszonej problematyki. Oprócz wymienionych wyżej uczestników z Wrocławia dołączyli psychologowie i pedagodzy: prof. Zbigniew Skorny, dr Maria Anduszko, dr Franciszek Futyma, dr Joanna Przesmycka-Kamińska, dr Ludwika Nicz, dr. Stanisław Witkowski, magistrowie Danuta Bocheńska, Wanda B. Dąbek, Alicja Gawłowska, Grażyna Greń, Małgorzta Kellerman, Teresa Łyżwa, Anna M. Mirtyńska, Anna Oleszkowicz, Maria Rymarska, Krystyna Szmajke; poza tym dr Jan Miodek - polonista językoznawca, czyli pracownicy Uniwersytetu Wrocławskiego lub osoby z nim współpracujące, oraz dr Roman Saczkowski, aktywista wrocławskiej „Solidarności”. Znaczną grupę tworzyli specjaliści w zakresie badań rehabilitacji: doc. dr hab. Tadeusz Gałkowski z UW i doc. dr Janusz Kostrzewski z Wyższej Szkoły Pedagogiki Specjalnej w Warszawie oraz dr Jan Pilecki i dr Władysława Pilecka z Wyższej Szkoły Pedagogicznej w Krakowie. UJ reprezentowała dr Jadwiga Włodek-Chronowska; KUL doc. dr hab. Teresa Kukołowicz; Uniwersytet Warszawski i Towarzystwo Rozwoju Rodziny doc. dr hab. Maria Trawińska. Prof. Stanisław Szajek z UAM nie był obecny, ale wydelegował dr Janinę Dobosz z WSP w Szczecinie, zaś z WSP w Bydgoszczy dołączył doc. dr hab. Zygmunt Wiatrowski i dr Teresa Hejnicka-Bezwińska jako niezależni badacze. 


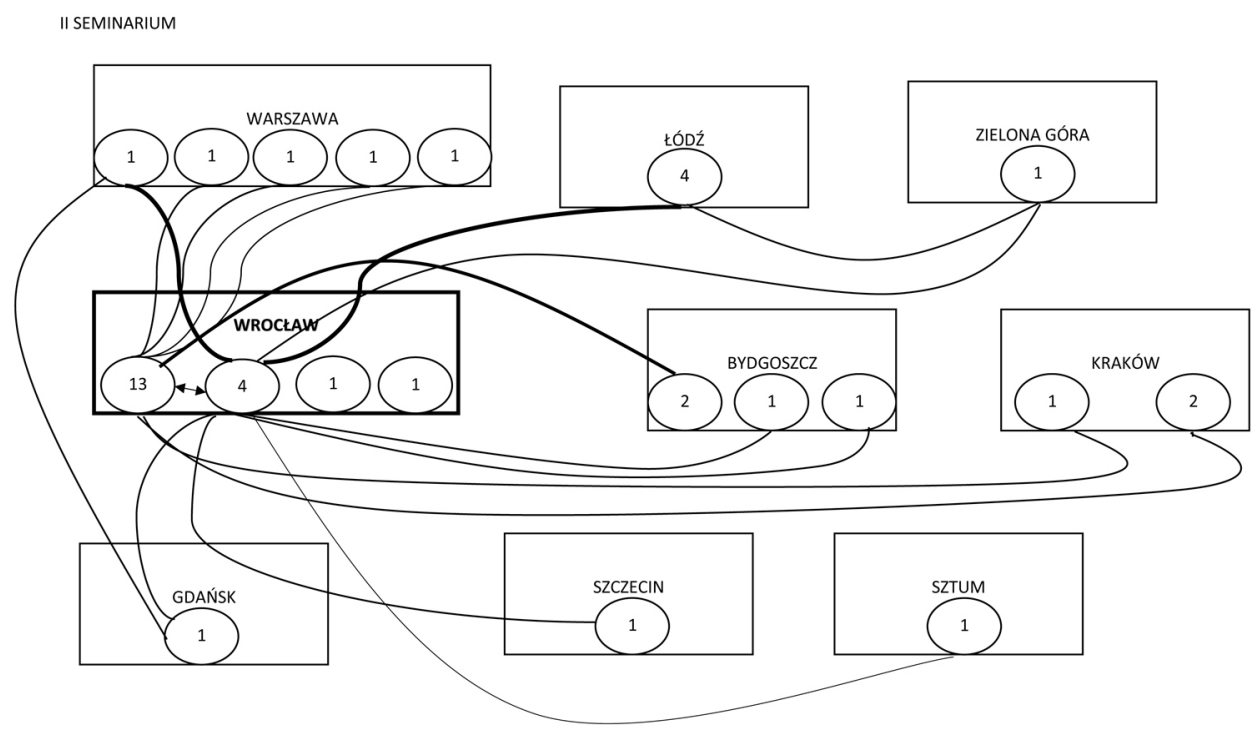

Rys. 2. Sieć II seminarium badań nad poradnictwem

Gdyby wziąć pod uwagę nie tyle miasta, ile poszczególne ośrodki reprezentowane na seminarium, czyli mówiąc językiem sieci - lokalne węzły - to można łatwo policzyć, że na pierwszym spotkaniu było ich jedenaście, w tym trzy z Warszawy; na drugim dwadzieścia dwa, w tym pięć z Warszawy, sześć z Wrocławia, dwa z Krakowa, trzy z Bydgoszczy i po jednym z innych miast, skupiając różną liczbę członków. Tak wieloosobowa zróżnicowana „statusowo”, wiekowo i merytorycznie grupa ludzi z jednej strony zdawała się stwarzać znaczne możliwości zadzierzgnięcia nowych więzi, z drugiej, z racji przewagi ludzi młodych, powodowała pewne rozproszenie i nie sprzyjała pogłębionym dyskusjom. Debaty, które miały prowadzić do rozwoju nowej nauki - poradoznawstwa - wymagały bowiem utworzenia się sieci elitarnej, nie tyle wieloosobowej, ile przygotowanej merytorycznie i skoncentrowanej na problemie. Doszło więc do pewnych przesunięć i ten skok w ilościowym rozwoju sieci nie utrzymał się do końca. Sieć merytoryczna, jaka wyłoniła się w obradach tego spotkania, zasadniczo nie uległa jakiejś trwałej zmianie, poza jedną. W toku obrad, wyraźniej niż poprzednio, zarysowała się bowiem kwestia poradnictwa rodzinnego, oglądana $\mathrm{z}$ dwóch perspektyw: laickiej socjologicznej, reprezentowanej przez doc. dr hab. Marię Trawińską w referacie Społeczne przestanki koncepcji poradnictwa ze szczególnym uwzględnieniem poradnictwa rodzinnego i ideologicznej, opartej na nauce Kościoła katolickiego doc. dr hab. Teresy Kukołowicz w referacie $Z$ historii, rozwoju i doskonalenia poradnictwa parafialnego. Tym samym poradnictwo rodzinne stało się nowym (5) węzłem $\mathrm{w}$ sieci obrad seminaryjnych. Wprawdzie pojawił się w nich także jeszcze jeden nowy wątek związany z rehabilitacją osób niepełnosprawnych, ale problematyka 
poradnictwa dla tych osób albo wiązała się z nakreślonym przez prof. Czerniawską poradnictwem dla dorosłych, czyli z podejściem andragogicznym, albo z poradnictwem zawodowym, rodzinnym lub egzystencjalnym, stanowiącym przedmiot rozważań powstałych przedtem ,,węzłów”. Na tym seminarium znacznie rozbudowały się bowiem dwa wcześniej wyłonione węzły tematyczne: psychologiczne poradnictwo egzystencjalne, którego analizę podjęli prawie wszyscy uczestniczący w obradach psychologowie wrocławscy oraz niezależnie kontynuował doc. dr Kaja z zespołem, oraz refleksja poradoznawcza, dotycząca specyficzności poradnictwa poprzez podjęcie jej przez dr. Mariana Jędrzejczaka rozważającego Problem klasyfikacji faktów i zjawisk poradnictwa, dr. Jana Miodka językoznawcy wprowadzającego nas w Poradnictwo językowe - teoria i praktyka i dr Włodek-Chronowską z Uniwersytetu Jagiellońskiego przestawiającą referat Próba uporządkowania terminologii poradnictwa i hierarchii jego celów ${ }^{3}$.

\section{Apogeum rozwoju seminaryjnej sieci}

Trzecie seminarium (Karpacz, 2-6.V.1983) było już dość dobrze opanowanym organizacyjnie wydarzeniem. Jedną z przyczyn zmian ,terytorialnych” i merytorycznych, jakie zaszły w seminaryjnej grupie, mógł być temat uściślający jego główny cel: Teoretyczne $i$ metodologiczne problemy poradoznawstwa. W tak zatytułowanych obradach oprócz stałych członków nieco okrojonego zespołu prof. Kulczyckiego, który swoją obecnością wzmocnili jednak dr Michał Dąbek, mgr Krystyna Węgłowska-Rzepa i wsparł tematycznie doc. dr hab. Paweł Boesler z Wojskowej Akademii Politycznej z Warszawy, uczestniczyli niezależni badacze z różnych nowych środowisk: doc. dr hab. Maria Manturzewska i mgr Kalina Statkiewicz z Akademii Muzycznej w Warszawie; doc. dr Stefania Słyszowa z Instytutu Badań nad Młodzieżą w Warszawie, dr Henryk Dolecki, prawnik z Uniwersytetu Wrocławskiego; dr Kazimierz Frieske - socjolog z Uniwersytetu Warszawskiego; dr Róża Pawłowska z Uniwersytetu Gdańskiego; dr nauk medycznych Aldona Sito z Instytutu Matki i Dziecka w Warszawie. W sumie liczba ośrodków, z których przybyli uczestnicy obrad, była mniej liczna - dziewiętnaście, podobnie jak i jej skład, który jednak był bardziej zróżnicowany pod względem tematyki prowadzonych badań. Obecność samodzielnych badaczy była o wiele bardziej sprzyjająca utrzymywaniu się mniej gęstej, ale i tak znacznie rozbudowanej sieci.

\footnotetext{
Na marginesie trzeba dodać, że przywołany tu podział węzłowych tematów podjętych na seminarium nie jest oparty na jakiejś ściśle określonej metodzie klasyfikacji. Gdyby podjąć trud choćby semantycznej analizy wygłoszonych treści, okazałoby się, że ich struktura ma kształt powikłanej sieci, neologizmów, zapożyczeń, określeń wieloznacznych, cytatów itp., komplikując możliwość dokonywania podziałów, a tym samym powodując małą precyzyjność klasyfikowania rozważanej problematyki.
} 


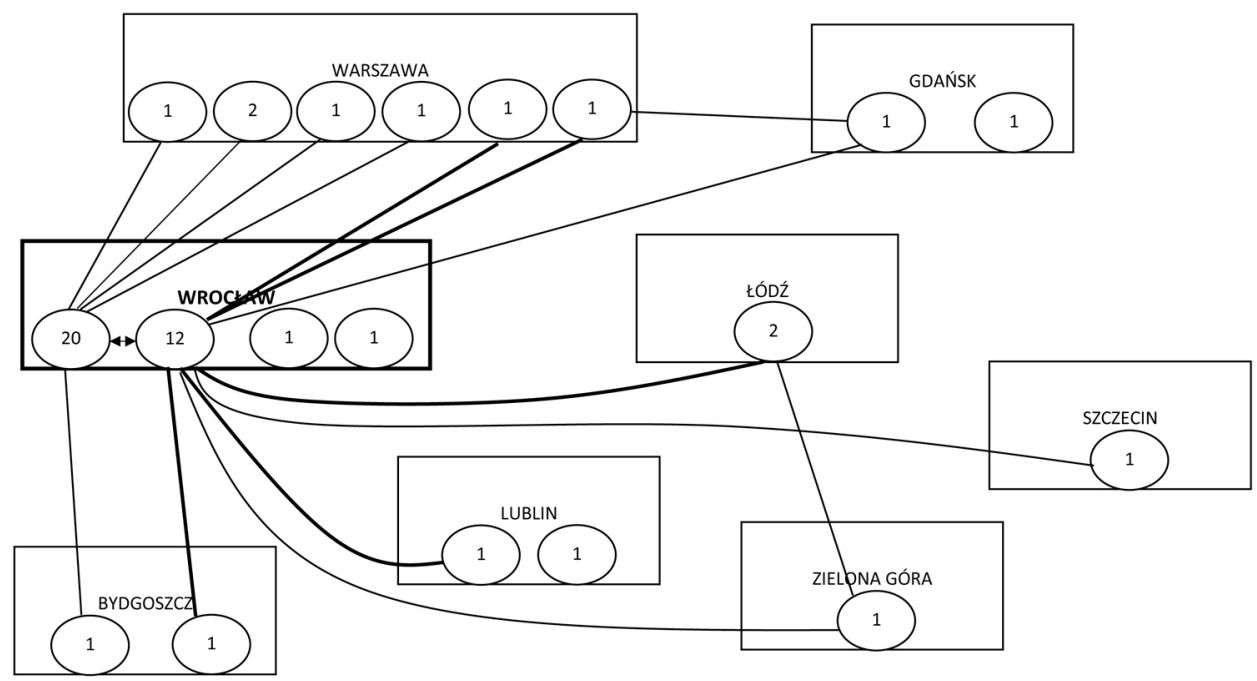

Rys. 3. Sieć III seminarium badań nad poradnictwem

Lista uczestników sieci terytorialnej seminarium (określanej miastem, z którego pochodzili uczestnicy) uległa tu zmianie, a obrady dotyczące węzłowych zagadnień przyjęły bardziej zwarty charakter. I tak psychologiczne podstawy poradnictwa egzystencjalnego, który otwierał referat prof. Kulczyckiego pt. Zarys relacyjnej koncepcji poradnictwa, w poszczególnych wystąpieniach członków jego zespołu został uszczegółowiony i rozwinięty, gdyż rozpatrywano: specyficzność tegoż poradnictwa, wyznaczniki stopnia optymalności porady, problem gotowości jednostki do jej przyjęcia, zagadnienie normy w poradnictwie, rodzaje nawiązywanych w nim interakcji i ich ocenę ze względu na rodzaj udzielonej pomocy i poziomu przygotowania doradcy do jej udzielania. Taka pogłębiona analiza psychologiczna poradnictwa, podjęta przez wrocławskich psychologów, dawała podstawę merytoryczną dalszym jego penetracjom i wzbogacała wiedzę poradoznawczą $\mathrm{w}$ aspekcie poznawania specyfiki przeżyć i doświadczeń poszczególnych uczestników sytuacji poradniczej.

Podstawy teoretyczne i metodologiczne dwóch innych węzłów także zostały mocniej wyakcentowane. Poradnictwa zawodowego dzięki obszernemu referatowi doc. dr Rachalskiej Metodologiczne i teoretyczne podstawy poradnictwa zawodowego; zaś poradnictwa rodzinnego dzięki trzem referatom: doc. dr hab. Kukołowicz Podstawy teoretyczne parafialnego poradnictwa rodzinnego; doc. dr hab. Czerniawskiej Rola poradnictwa przedmatżeńskiego i matżeńskiego oraz jego efektywność oraz doc. dr hab. Trawińskiej Projekt rozwoju $i$ koordynacji poradnictwa rodzinnego w Polsce. O ile Kukołowicz oparła swoją wypowiedź o personalizm Karola Wojtyły, Czerniawska podtrzymała orientację andragogiczną $\mathrm{w}$ analizach poradnictwa rodzinnego, a Trawińska przyjęła stanowisko polityka socjalnego. Każdy z tych referatów wnosił coś nowego do naukowej 
wiedzy poradoznawczej, jednak w jej porządkowaniu znaczącą rolę odegrały inne wystąpienia: dr Teresy Hejnickiej-Bezwińskiej Refleksje nad strukturą i treścia teorii poradnictwa, dr. Kazimierza Frieske Dylematy doradztwa naukowego: wiedza naukowa vs zdrowy rozsądek, dr. Mariana Jędrzejczaka Rodzaje wiedzy a struktura podstaw naukowych poradnictwa wychowawczego i wypowiedź zapowiadająca krytyczne podejście metodologiczne doc. dr. hab. Józefa Kargula Kilka uwag o niebezpieczeństwach poradnictwa. Pozostałe wypowiedzi, podobnie jak poprzednio, wiązały się z tematami wiodącymi. Szczegółowo rozpatrywano w nich różnorodne okoliczności wykorzystania poradnictwa, np. w pracy Akademii Muzycznej w Warszawie, telewizji, zakładzie produkcyjnym itp. Ponieważ struktura terytorialna seminarium w porównaniu z poprzednim nie uległa na tyle zmianie, żeby miało to znaczenie dla prowadzonej tu analizy - zrezygnuję z jej przedstawiania.

Seminarium czwarte Perspektywy rozwoju teorii i praktyki poradnictwa (Karpacz, 13-18.V.1985) to powrót do rozbudowywania sieci połączeń, przede wszystkim poprzez zwiększenie liczby uczestników i ilości ośrodków, które reprezentowali. W dalszym ciągu uczestniczy w nim zespół inicjatorów oraz grupa pedagogów i psychologów wrocławskich w nieco zmienionym składzie z doc. dr. hab. Zygmuntem Szulcem, dr Krystyną Ferenz i mgr. Ryszardem Poprawą. Prof. Czerniawska bierze w nich udział z uczniem dr Kazimierzem Zawadzkim; prof. Rachalska z uczennicą dr Bożeną Krzeszewską oraz liczna grupa niezależnych badaczy z różnych ośrodków, a także doradcy-praktycy - w sumie 60 osób. Z moich obliczeń wynika, że można tu mówić aż o 33 ośrodkach ulokowanych w 12 polskich miastach i jednym w czeskim - Pradze, co w przybliżeniu oddaje poniższy wykres.

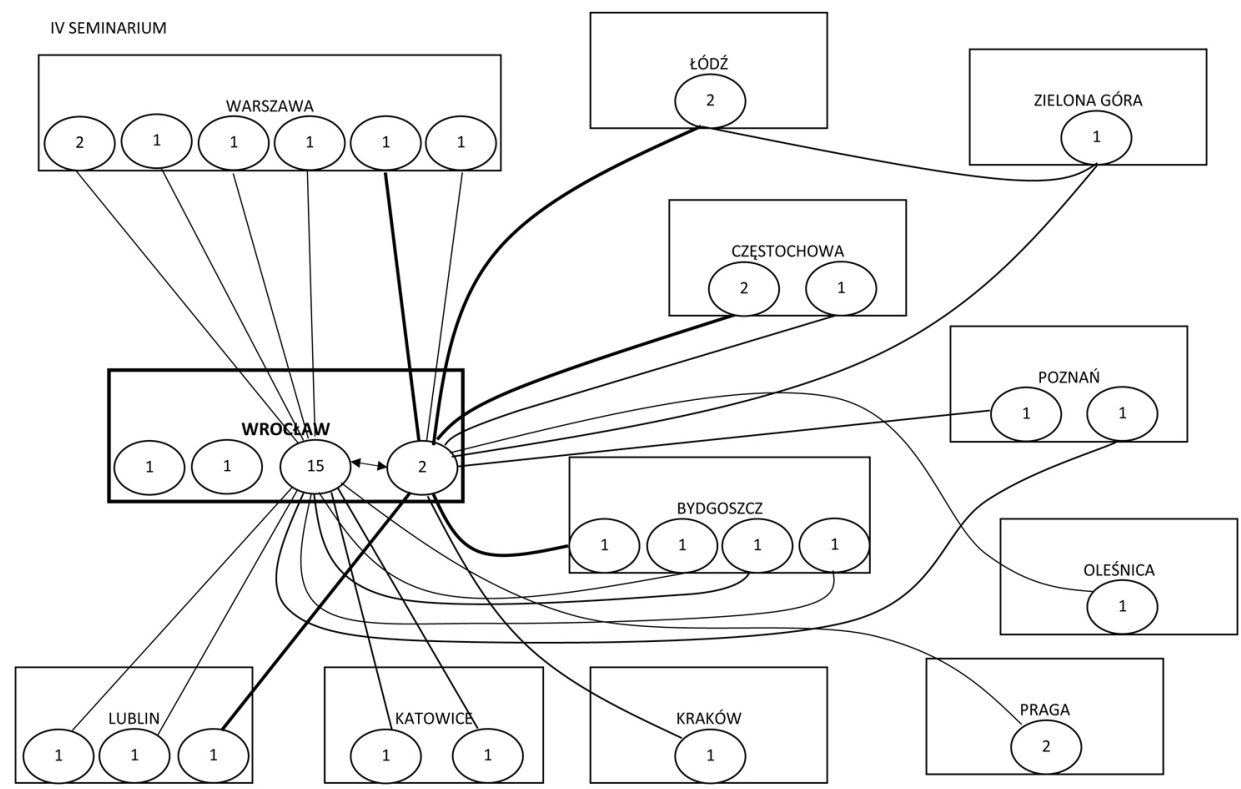

Rys. 4. Sieć IV seminarium badań nad poradnictwem 
Spoglądając na tę strukturę sieci badaczy poradnictwa i mając na względzie jej wcześniejszy kształt i dalsze przekształcenia „terytorialne”, można stwierdzić, że tutaj osiągnęła apogeum rozwoju, jeśli chodzi o liczbę tworzących ją węzłów i uczestniczących osób. Jak jednak okazało się, w tym aspekcie jej trwałość była bardzo krucha. $Z$ punktu widzenia ogólnego celu seminarium ważne zdawało się być bowiem nie tyle poszerzanie kręgów dyskutantów, ile pogłębianie dyskusji w obrębie podjętych już wcześniej węzłowych jego zagadnień, uzgadnianie pojęć, dochodzenie do pewnych wniosków, dokonywanie podsumowań i uogólnień, czyli budowanie i podtrzymywanie wspólnoty myślenia. Dobrze rozumieli to stali uczestnicy seminarium, którzy nie odeszli od podjętej przez siebie problematyki i wcześniejszych ustaleń. Węzłowe zagadnienie, jakim cały czas były psychologiczne podstawy poradnictwa egzystencjalnego, wzmocnili referatami Podstawy porady życiowej prof. Kulczycki i Teoretyczne podstawy poradnictwa dla osób niepetnosprawnych prof. Skorny z Uniwersytetu Wrocławskiego; oraz wystąpienia Hermeneutyczne aspekty procesu porady a przesłanki rozwoju poradnictwa dr. Andrzeja Klimentowskiego, czy Strategia poradnictwa w świetle koncepcji Tadeusza Tomaszewskiego doc. dr. hab. Romana Ossowskiego z Bydgoszczy. Tematykę o charakterze naukowotwórczym Problemy etyki zawodowej w poradnictwie psychologicznym poruszył doc. dr hab. Wojciech Poznaniak z UAM w Poznaniu. Prof. Rachalska nie odchodząc od zagadnień poradnictwa zawodowego, podjęła trud integracji wiedzy w referacie Możliwości wykorzystania psychologii i pedagogiki w konstruowaniu teorii poradnictwa zawodowego. W tym obszarze badań znalazł się także dr Andrzej Sękowski (UMCS) z referatem Zastosowanie analizy decyzyjnej w poradnictwie zawodowym oraz w jakimś sensie dr Władysława Błońska (UŚ) rozpatrująca Wkład Psychotechniki do rozwoju zawodoznawstwa w Polsce w latach 1927-1939.

Znaczne zainteresowanie znalazło tu poradnictwo rodzinne, zwłaszcza dedykowane rodzinom doświadczającym różnego rodzaju problemów: posiadanie dziecka autystycznego (doc. dr hab. Tadeusz Gałkowski UW), głuchego lub niedosłyszącego (doc. dr hab. Maria Góralówna - UW, dr Marian Jędrzejczak i mgr Wacława Sumara - UWr.), niedowidzącego i niewidomego (dr Ewa Bendych - WSPS, mgr Urszula Niesiołowska i dr Marian Jędrzejczak - UWr.) wymagającej psychoprofilaktyki (doc. dr hab. Helena Sęk - UAM), psychoterapii (doc. dr hab. Heszen-Klemens - UŚ), opieki psychologiczno-pedagogicznej (mgr Elżbieta Gałecka - Centralny Ośrodek Poradnictwa Wychowawczo-Zawodowego), oraz pomocy w postępowaniu przed sądem (dr Henryk Dolecki - UWr. i dr Ludmiła Pęska - Rodzinny Ośrodek Diagnostyczno-Konsultacyjny Ministerstwa Sprawiedliwości). W niewielkim jednak stopniu nawiązywały te referaty do wcześniej wypracowanej na seminarium ogólnej wiedzy na temat poradnictwa rodzinnego. Znawczynie problematyki tego poradnictwa, doc. dr. hab. Kukołowicz i doc. dr hab. Trawińska, kontynuowały uogólnioną refleksję nad nim, wzmacniając tym samym dyskurs węzła podejmującego się budowania ogólniejszej teorii 
poradnictwa. W nurcie poradoznawczym pozostała dr Teresa Hejnicka-Bezwińska (WSP w Bydgoszczy) z referatem Zwiazek poradoznawstwa z poradnictwem, czyli tradycyjny dylemat teorii i praktyki i dr Kazimierz Frieske (UW) Doradztwo w rozmaitych koncepcjach spotecznego uwiktania jednostki, a wzmocnił go doc. dr hab. Paweł Boesler (Doradzanie w sytuacjach konfliktu międzyosobowego) i gość honorowy doc. dr hab. Janusz Goćkowski (UJ), rozważając naukoznawczą kwestię: Eklektyzm a interdyscyplinarność.

Prof. Olga Czerniawska nie rezygnując z podstaw andragogiki, wzbogaca ją o wiedzę z zakresu gerontologii, gdy przedstawia Poradnictwo dla osób starszych. Nie jest to porzucenie przez Nią dotychczasowego sposobu rozumienia poradnictwa andragogicznego, ale niejako naturalne rozwinięcie swojej wizji poradnictwa z uwzględnieniem etapów ludzkiego życia, w jakich może być ono udzielane. Było to wówczas nowe podejście do problematyki poradnictwa, zważywszy że termin „poradnictwo całożyciowe” wszedł do języka poradoznawstwa znacznie później.

\section{Rozrzedzenie się i zawieszenie sieci}

Obrady piątego seminarium odbywały się w okresie radykalnych zmian i gorących dyskusji politycznych, absorbujących niektórych uczestników, a nawet rozdzielających ich dotychczasowe przyjazne związki (Karpacz, 11-14.V.1987). Zachodzące zmiany starał się oddać tytuł seminarium Poradnictwo wobec złożoności problemów człowieka $i$ świata. Nadwątlona jego sieć objęła 31 badaczy pochodzących z 20 ośrodków, w tym jednego gościa z zagranicy, prof. Bernt-Joachima Ertelta z uczelni technicznej w Mannheim. Rozproszenie tych ośrodków nie było zbyt wielkie (8 miejscowości), a większość z nich była zlokalizowana w Warszawie - pięć; Wrocławiu - cztery; Zielonej Górze - dwa. Pojedynczo utrzymały się lokalne węzły w Częstochowie, Gdańsku, Katowicach, Lublinie, Łodzi i Poznaniu, jednakże przeważnie w innym składzie osobowym niż był dotychczas. Doszło zatem do skurczenia się liczby węzłów i rozproszenia się lokalnych badaczy poradnictwa.

Tendencję spadkową potwierdzać zdawało się kolejne szóste seminarium Poradnictwo w okresie transformacji kulturowej (Wrocław, 20-22.V.1993), w którym udział wzięło 31 osób nadal tylko z ośmiu ośrodków. Tutaj pojawiła się także nowa problematyka $\mathrm{w}$ różnym stopniu związana z ekonomizacją życia społecznego i rozwojem globalizacji (Zofia Ratajczak UŚ, Szczepan Skrzypiec UG, Zofia Waleria Stelmaszczuk UW, Marek Podgórny oraz Bogdan Sujak UWr.). Jedną z przyczyn osłabienia sieci mogło być przeniesienie obrad piątego seminarium z malowniczego Karpacza do Wrocławia, choć nigdy taki powód nie został wskazany. Niezmiennie uczestniczyli w nim pedagodzy i psychologowie z Uniwersytetu Wrocławskiego w liczbie 11 uczestników; pedagodzy społeczni i andragodzy - uczniowie prof. Olgi Czerniawskiej z Uniwersytetu Łódzkiego teraz w liczbie 4; trzej badacze z Uniwersytetu Warszawskiego; dwie badaczki z UAM w Poznaniu; 
dwie z WSP w Częstochowie; jeden z Uniwersytetu Gdańskiego; jedna z KUL; czyli w rezultacie uczestnicy seminarium pochodzący z siedmiu ośrodków akademickich, co bliskie jest strukturze terytorialnej pierwszego seminarium. Jednakże, jeśli chodzi o stałych uczestników w tym gronie, ich liczba jest dość skromna. Wśród jedenastu Wrocławian tylko pięciu jest stałymi członkami seminarium, uczestniczącymi w nim od początku albo od drugiego spotkania, podczas gdy pozostali w liczbie sześciu pojawili się na nim po raz pierwszy lub zaledwie drugi. Stali Łodzianie to prof. Czerniawska i dr Zawadzki; z Częstochowy stałą uczestniczką jest prof. Rachalska pracująca wcześniej w Instytucie Kształcenia Zawodowego w Warszawie; z KUL prof. Kukołowicz; a z Gdańska dr Skrzypiec. Pokazuje to, że zmiany w sieci badań nad poradnictwem obejmują nie tylko przekształcenia dotyczące rozległości sieci, dające się ująć w postaci danych ilościowych, ale także są obrazem jej trwałości. Nie wypada ona najlepiej. W seminarium bierze udział coraz mniejsza liczba stałych uczestników, członków wspomnianych węzłów. Pojawiają się na nim ci, którzy nie zajmowali się dotychczas badaniami poradnictwa, ale zamierzają je rozpocząć, mają jakiś pomysł i chcą się nim podzielić (dr Maria Czerwińska-Jasiewicz - UW, dr Katarzyna Popiołek - UŚ, dr Bożena Wojtasik, mgr Elżbieta Kalinowska oraz mgr Halina Sikora - Grabowska - UWr., mgr Iwona Kamosińska - WSP Częstochowa, mgr Magdalena Piorunek i mgr Grażyna Teusz - UAM) lub uważają, że ich przemyślenia są na tyle ogólne, że mogą być przydatne dla poradoznawców (dr hab. Robert Kwaśnica, dr hab. Mieczysław Malewski, dr hab. Bogdan Rok, mgr Ewa Kurantowicz oraz mgr Adam Nobis - UWr.). Taka sytuacja wskazuje potrzebę zmiany pomysłu na organizację sieci badań i metod rozwijania nauki o poradnictwie przez skoncentrowanie jej w mniejszych zespołach o lokalnym charakterze edukacyjnym.

Ostatnie seminarium Dramaturgia poradnictwa (Wrocław, 12-13.VI.1995) wprawdzie ze względu na tytuł niektórym skojarzyło się z dramatyczną ogólną sytuacją seminarium, jednakże w zamierzeniu zostało tak nazwane, by odzwierciedlać przełom metodologiczny, jaki nastąpił w badaniach społecznych. Schyłek metodologii badań ilościowych zainspirował inicjatorów seminarium do dyskusji o badaniach nad poradnictwem w paradygmacie humanistycznym (tu symbolicznego interakcjonizmu), którego początki zapowiadały już niektóre wcześniejsze pojedyncze wystąpienia. Analizując tę edycję seminarium jako zorganizowaną sieć badaczy poradnictwa, można łatwo zauważyć, że: po pierwsze następuje kurczenie się ilości węzłów, czyli ilości środowisk badawczych, po drugie zmienia się ich struktura określona liczbą samodzielnych niezależnych badaczy, pojedynczych osób lub zorganizowanych zespołów. Najogólniej oddaje ją poniższy wykres: 


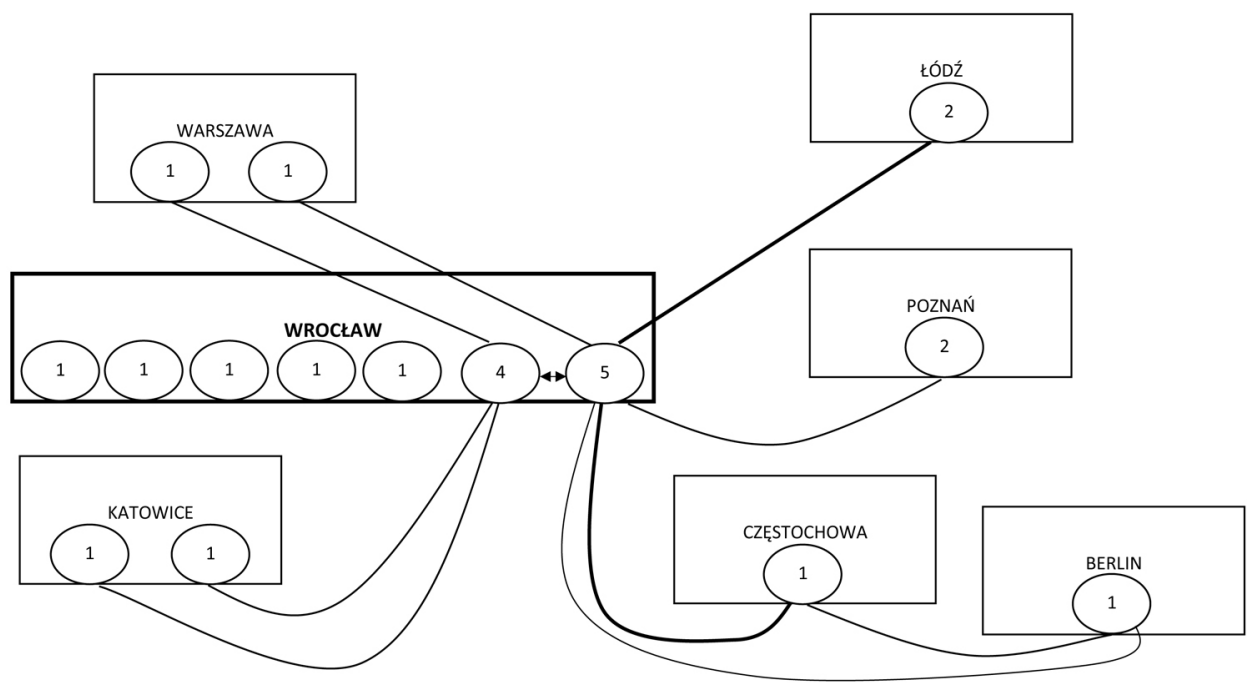

Rys. 5. Sieć VII seminarium badań nad poradnictwem

Jak widać, sieć obejmuje teraz sześć polskich miast i jedno zagraniczne Berlin, z tym że obecność pochodzących z nich 11 uczestników seminarium jest jednorazowa, żeby nie powiedzieć przypadkowa, a gościa zagranicznego Bernharda Jenschke, przewodniczącego Stowarzyszenia Doradców Szkolnych i Zawodowych (AIOSP/IAEVG) - kurtuazyjna. Ogólnopolskie seminarium przestaje mieć rację bytu, jeśli ma skupiać badaczy głównie z jednego środowiska - Wrocławia, a w niewielkim stopniu pozostawać w strefie zainteresowań czy dostępu dla innych ośrodków badawczych. Po zakończeniu obrad zapada więc decyzja jego całkowitego zamknięcia.

\section{Próba wyjaśnienia zachodzących zmian}

Wiele osób zadaje sobie pytanie, dlaczego tak się stało? Dlaczego główny trzon sieci, który stanowili wrocławscy pedagodzy i psychologowie, z których obecnie większość uzyskała stopnie samodzielnych pracowników naukowych, badacze tej miary co prof. Czerniawska z zespołem i prof. Rachalska z grupą młodych badaczy, a także pojawiająca się prężna grupa badaczy Uniwersytetu Śląskiego w Katowicach (prof. dr hab. Zofia Ratajczak, doc. dr hab. Irena Heszen-Klemens, dr Agnieszka Pietrzyk, dr Katarzyna Popiołek) i Uniwersytetu im. Adama Mickiewicza w Poznaniu (doc. dr hab. Helena Sęk, dr Magdalena Piorunek i mgr Grażyna Teusz) nie byli w stanie utrzymać i rozbudować sieci? Odpowiedź możemy znaleźć u Fergusona, który analizuje relacje między sieciami i hierarchiami, wskazując na bezsilność sieci wobec hierarchii i znaczącą rolę połączeń 
nieformalnych. Zdaniem tego autora, sieci o charakterze nieformalnym - a takie łączyły uczestników seminarium - powinny tworzyć się poprzez skoordynowane dziatanie jednostek zaangażowanych $w$ operacje majace na celu odwzajemnienie przystug, urzeczywistnianie preferencji $i$ wzajemne wspieranie się (Ferguson, 2020, s. 49). Takie sieci, jeśli mają być trwałe, wymagają bliskości, jednomyślności, tolerancji dla odmienności, swobody działania. Takie sieci tworzą się w sposób naturalny, nie muszą być zbyt mocne, najczęściej są niezależne od żadnej hierarchii. Jednakże, jeśli ma miejsce ich zależność, ich żywot zapewnić może bycie przydatnymi dla układu hierarchicznego, w którym mogą tkwić, lub siła, by z nim walczyć w sytuacji konfliktu.

Seminarium Poradnictwo we współczesnym społeczeństwie było siecią utworzoną głównie z pracowników uczelni akademickich. Hierarchiczna struktura tych uczelni nie zauważała konfliktu interesów, jaki mogła wywoływać aktywność ich pracowników poza uczelnią dopóty, dopóki uczelnie dysponowały odpowiednimi środkami finansowymi, umożliwiającymi zaspokojenie potrzeb tych pracowników związanych z ich wyjazdami, kilkudniową nieobecnością, a przede wszystkim samodzielnością w podejmowaniu decyzji co do zakresu prowadzonych badań, zgodnych lub niezgodnych z ogólnie przyjętą polityką uczelni. W konfrontacji ze zmienioną ogólną polityką szkolnictwa wyższego krucha sieć poradoznawczych badań okazała się być zbyt słaba, aby przetrwać. W praktyce, w roku 1979, w którym powstawała, uczestnicy seminarium mieli zapewnione: zakwaterowanie i pełne wyżywienie w miejscowości, w której odbywały się obrady (Wrocław, Karpacz, Wrocław), całkowity zwrot kosztów podróży, wynagrodzenie za przygotowanie i wygłoszenie referatu, publikację wystąpienia po uzyskaniu pozytywnych recenzji, egzemplarz autorski materiałów z seminarium, dziesięć do dwudziestu „nadbitek” wydrukowanego własnego artykułu. Wszystkie związane z tym koszty ponosiła jednostka organizująca, czyli Uniwersytet Wrocławski. Zmiany ustrojowe nie były tu jednak bez znaczenia, zgodnie z tym, co stwierdza Ferguson (2015, s. 36), że zależności między ekonomia i polityka sa tak naprawdę kluczem do zrozumienia świata. Sytuacja polityczna nie tylko zaważyła na międzyosobowych kontaktach uczestników będących zwolennikami różnych opcji, przyczyniając się czasem do zerwania osobistych więzi, ale i na warunkach ekonomicznych spotykania się. Zmieniona polityka finansowania uniwersytetów znacznie ograniczyła możliwości organizowania konferencji na opisanych wcześniej warunkach, a więc i wspomnianego seminarium. Znacznie zawęziło to zasięg sieci, odcinając od niej osoby, nie dysponujące odpowiednimi środkami niezbędnymi dla pokrycia kosztów związanych z pełnym udziałem w seminarium, odbywającym się poza miejscem zamieszkania. Już na piątym spotkaniu kilku uczestników swój udział ograniczyło do jednodniowego pobytu lub do przyjścia dla wygłoszenia referatu. Teraz ta forma udziału zdominowała obrady. Wzajemna wymiana usług w postaci dyskusji, podejmowania wspólnych badań i korzystania z merytorycznych porad, znacznie osłabła. Zmieniły się także na niekorzyść mikrowarunki nawiązywania 
nieformalnych więzi, jakie miały miejsce z racji wspólnego zakwaterowania, udziału w ,przerwach kawowych”, rozmowach wieczornych i nocnych. Seminarium straciło swój seminaryjny charakter, przestawało być platformą tworzoną dla wymiany poglądów, spotykania się ludzi - członków lokalnych sieci bądź osób dążących do nawiązania nowych - a stawało się konferencją umożliwiającą wygłoszenie lub wysłuchanie referatu często osoby wcześniej nieznanej lub słabo zainteresowanej problematyką seminarium. Ale to nie tylko w tym tkwi przyczyna jego końca.

Słabość seminarium jako sieci brała się także ze słabości więzi merytorycznej, łączącej jego uczestników, a wyrażającej się dążeniem dopracowania się takiej teorii, w której precyzyjnie określony przedmiot badań dostarczałby ram dla krytycznego rozumienia, charakterystycznych dla poradnictwa zjawisk i stanowił podstawę uporządkowania ich rozpoznawanych aspektów. Teorii, która operowałaby własną terminologią, stanowiącą uporzadkowany zbiór pojęć stużący zdefiniowaniu oraz wyjaśnieniu pewnego zjawiska (Silverman, 2009, str. 146), jakim w tym wypadku jest poradnictwo. Osiągnięcie tego celu sieci nie dokonało się nie tylko za sprawą siły i słabości jego węzłów: kondycji intelektualnej inicjatorów i uczestników (choć z pewnością nie były one bez znaczenia), ale także zmian dotyczących sposobu uprawiania nauk humanistycznych i społecznych. Seminarium rodziło się w okresie paradygmatycznego przełomu. Rezygnacja z wymagań pozytywizmu oraz dominacja postmodernizmu w nauce i nowe określenie roli uczonego musiały zaważyć na przekształceniu celu seminarium jako intelektualnej sieci. Zaniechanie budowania nauki jako systemu twierdzeń i ścisłych praw na rzecz konstruowania sieci dyskursów opartych na rozumieniu i interpretacji zjawisk nie przez wszystkich zostało zaakceptowane. Być może zbudowanie seminarium nie jako partnerskiej sieci, ale jako hierarchicznej struktury, kierowanej przez jednego badacza, bezwzględnie realizującego swój naukowy plan i reklamującego go w sieci publikatorów, zapewniłoby mu dłuższy żywot. Tak jednak nie było i nie jest to takie pewne, zważywszy na zmienne trajektorie rozwoju nauki w ogóle.

\section{Zakończenie}

Zachodzące zmiany prowadzące do zaniechania spotkań szczególnie mocno odczuwała prof. Czerniawska jako stała, zaangażowana współtwórczyni seminarium. Po jego zamknięciu niejednokrotnie dopominała się wielostronnej analizy jego osiągnięć. Było to oczekiwanie w pełni uzasadnione, gdyż starannie przygotowując ważne referaty nie tylko inspirowała swoich uczniów (doktorów: Barbarę Juraś-Krawczyk, Marka Pryta i Kazimierza Zawadzkiego) do badań poradnictwa, nie tylko zobowiązywała nas do dbania o wysoki poziom obrad, ale wielokrotnie wzbogacała je swoimi wspomnieniami na temat doświadczeń związanych z własną poradniczą praktyką; na temat znanych sobie badań międzynarodowych nad poradnictwem prowadzonych we Francji; na temat dyskusji dotyczących biograficzności 
i roli w niej poradnictwa. Jej udział w seminarium był jednym z kluczowych warunków jego trwania i rozwoju. Uczestniczyła w nim od pierwszego do ostatniego spotkania, cały czas mając nadzieję, że jego rezultaty nie pójdą na marne. Tak się też w jakimś stopniu stało. Teksty wygłoszonych przez Nią referatów (Czerniawska, $1980 ; 1982 ; 1985 ; 1988 ; 1990 ; 1995 ; 1996)$ dają mocne podstawy poradnictwu andragogicznemu i gerontologicznemu (Kargulowa, 2015; Woźnicka, 2015) Z kolei umiejętność bycia w sieci, zaangażowanie, poczucie odpowiedzialności i dążenie do uwspólnienia badań, pomimo późniejszej zmiany przez Nią pola zainteresowań, cały czas pozostają dla nas ważną wskazówką, jak od nowa budować sieć badań nad poradnictwem.

\section{Bibliografia}

Castells M. (2008). Społeczeństwo sieci, przekład zespół, red. nauk. M. Marody. Warszawa: Wyd. Nauk. PWN.

Czerniawska, O. (1977). Poradnictwo jako wzmacnianie środowiska wychowawczego. Warszawa: Instytut Wydawniczy CRZZ.

Czerniawska, O. (1980). Poradnictwo wychowawcze dla dorosłych. W: A. Kargulowa, M. Jędrzejczak (red.), Rola poradnictwa i doradztwa w optymalizowaniu rozwoju osobowości i podnoszeniu kultury pedagogicznej spoleczeństwa, AUW no 608. Wroclaw: Wyd. UWr., s. 195-207.

Czerniawska, O. (1982). Poradnictwo jako pomoc w rozwoju (na przykładzie popularyzacji wiedzy o wychowaniu wśród rodziców). W: A. Kargulowa, M. Jędrzejczak (red.), Spoleczne i jednostkowe znaczenie poradnictwa. AUW, no 662. Wrocław: Wyd. UWr., s. $159-177$.

Czerniawska, O. (1985). Rola poradnictwa przedmałżeńskiego i małżeńskiego oraz jego efektywność. W: A. Kargulowa, M. Jędrzejczak (red.), Teoretyczne i metodologiczne problemy poradoznawstwa, Vol. II. AUW, no 811. Wrocław: Wyd. UWr., s. 327-338.

Czerniawska, O. (1988). Poradnictwo dla osób starszych. W: M. Jędrzejczak, A. Kargulowa (red.), Perspektywy rozwoju teorii i praktyki poradnictwa. Vol. II. AUW, no 1001. Wrocław: Wyd. UWr., s. 13-27.

Czerniawska, O. (1990). Koncepcja orientacji szkolnej i poradnictwa zawodowego Geneviéve Latreille. W: A. Kargulowa (red.), Poradnictwo wobec zlożoności problemów czlowieka i świata. Vol. I. AUW, no 1249. Wrocław: Wyd. UWr., s. 319-329.

Czerniawska, O. (1995). Poradnictwo dla osób starszych. W: A. Kargulowa (red.), Poradnictwo w okresie transformacji kulturowej. AUW, no 1700. Wrocław: Wyd. UWr., s. 193-197.

Czerniawska, O. (1996). Nieformalne doradztwo dla ludzi starszych. W: A. Kargulowa (red.), Dramaturgia poradnictwa. AUW, no 1889. Wrocław: Wyd. UWr., s. 59-63.

Ferguson, N. (2015). Niebezpieczne zwiazki. Pieniadze i władza w świecie nowożytnym $1700-2000$, przełożył W. Tyszka. Kraków: Wydawnictwo Literackie.

Ferguson, N. (2020). Rynek i ratusz. O ukrytej sieci powiazań, która rządzi światem, przełożył W. Tyszka. Kraków: Wydawnictwo Literackie.

Kargulowa, A. (2015). Profesor Olgi Czerniawskiej wizja poradnictwa andragogicznego i gerentologicznego. W: E. Woźnicka, A. Stopińska-Pająk (red.), Oświata dorostych. 
Inspiracje $i$ wyzwania: tom dedykowany Profesor Oldze Czerniawskiej z okazji 85.urodzin. Łódź: Wyd. Akademii Humanistyczno-Ekonomicznej w Łodzi, s. 47-59. Kargulowa, A. (2018). Edukacja, praca, rodzina w trzech koncepcjach poradnictwa lat osiemdziesiątych. Profesorowi Tadeuszowi Aleksandrowi z okazji Jubileuszu. W: A. Chabior (red.), Uczacy się dorosty - inspiracje, wyzwania, trendy. Księga Jubileuszowa poświęcona Profesorowi Tadeuszowi Aleksandrowi w 80. rocznice urodzin i 55. rocznicę pracy naukowej. Ostrowiec Świętokrzyski: Wyższa Szkoła Biznesu i Przedsiębiorczości w Ostrowcu Świętokrzyskim, s. 77-104.

Silverman, D. (2009). Prowadzenie badań jakościowych, tłum. J. Ostrowska, Warszawa: WN PWN.

Woźnicka E. (2015). Biografia i obszary poszukiwań naukowo-badawczych Profesor Olgi Czerniawskiej. W: E. Woźnicka, A. Stopińska-Pająk (red.), Oświata dorosłych. Inspiracje $i$ wyzwania: tom dedykowany Profesor Oldze Czerniawskiej z okazji 85. urodzin. Łódź: Wyd. Akademii Humanistyczno-Ekonomicznej w Łodzi, s. 25-46.

\section{Professor Olga Czerniawska the co-creator of the counseling research network}

Keywords: counselling, counsellogy, social networks, hubs and concentrators.

Summary: The article contributes to the historiography of counsellogy by analysing the development of research on counselling in the years 1979-1995. Network theory was used as a tool for description and analysis, indicating how the personal and functional relationships of counselling researchers in that period led to the beginning of the formation of new science. At the same time, it allowed to emphasise the role played by Professor Olga Czerniawska. The meaning of the text is reinforced by network drawings presenting the structures of selected seminars "Counselling in contemporary society".

Dane do korespondencji:

Prof. dr hab. Alicja Kargulowa

jozef.kargul@dsw.edu.pl 